\title{
LUT
}

University

\section{Industrial Ecology in Support of Sustainable Development Goals}

\author{
Awan Usama
}

This is a Author's accepted manuscript (AAM) version of a publication

published by Springer

in Leal Filho, W., Azul, A., Brandli, L., Özuyar, P., Wall, T. (Eds.) Responsible Consumption and Production. Encyclopedia of the UN Sustainable Development Goals.

DOI: 10.1007/978-3-319-71062-4_18-1

Copyright of the original publication: () Springer Nature Switzerland AG 2020

Please cite the publication as follows:

Awan, U. (2020). Industrial Ecology in Support of Sustainable Development Goals. In: Leal Filho, W., Azul, A., Brandli, L., Özuyar, P., Wall, T. (Eds.) Responsible Consumption and Production. Encyclopedia of the UN Sustainable Development Goals. Springer, Cham. DOI: 10.1007/978-3-319-71062-4_18-1

This is a parallel published version of an original publication. This version can differ from the original published article. 
(C) Springer Nature Switzerland AG 2020

Responsible Consumption and Production

Encyclopedia of the UN Sustainable Development Goals

10.1007/978-3-319-71062-4_18-1

\section{Industrial Ecology in Support of Sustainable Development Goals}

Usama Awan $^{1}$

(1)Industrial Engineering and Management, Lappeenranta-Lahti University of Technology, Lappeenranta, Finland

Usama Awan

Email: Usama.Awan@lut.fi

Email: awan.usma@gmail.com

\section{Citations:}

Usama Awan (2019), Industrial ecology in support of sustainable development goals. W. Leal et al. (eds.), in Encyclopedia of the UN Sustainable Development Goals (UNSDGs), SDG 12, Springer Nature Switzerland AG.ISSN: 978-3-319-71062-4. Springer International Publishing, 1-12.. DOI: https://doi.org/10.1007/978-3-319-71062-4. 978-3-319-71062-4

\section{Definitions}

Industrial ecology is a subdiscipline of the natural ecosystem which aims to restructure the industrial ecosystem in ways of managing and designing linear to closed-loop industrial production and consumption system. Industrial ecology seeks to form a harmonized relations between ecological and human system to provide sustainable benefits of all aspects of sustainability including social, environmental, and economic.

\section{Introduction}

In this era of immense ecological change and environmental uncertainty, bring to fore by the wideranging effects on energy use, depletion of resources, waste of water resources, global warming and sustainable consumption and production of materials. The concept of industrial ecology (IE) has gained a significant attractive feature of the broader implementation of Sustainable Development Goals(SDGs). IE tools and practices can be used to address global sustainability challenges for sustainable consumption and production through SDGs 2030. The benefits of SDGs12 lie in the pursuit of industrial ecology initiatives within the fields of strategic management, supply chain, marketing, industrial economics, and consumer behavior. However, research on industrial ecology is unexpectedly limited in the strategic innovation management and marketing literature and has mainly focused on the industrial ecosystem, political ecology, and industrial symbiosis. While major 
of the literature on IE focuses on efficient use of material and energy between networks of firms, it provides a limited perspective on the forms of IE in advancing the United Nations Sustainable Development Goals. The proposed study could shed light on developing a better understanding of the process of advancing and supporting IE in business firms and mechanism through which firms in networks to achieve triple bottom-line benefits.

The year 1970 is generally thought of as the industrial ecology revolution in the word (Stern 1973). The idea of industrial ecology (IE) is about waste as by-products reused by other products. Frosch and Gallopoulos first used the word industrial ecology as a field of manufacturing strategies in 1989, and it came into broader application in the last two decades. Industrial ecology (IE) was not acknowledged mainly as a system approach until the last half of the nineteenth century. When Frosch and Gallopoulos expressed concern about both manufacturer and consumers from developing and developed countries must change their habits to proceed to a more harmonious industrial ecosystem (Frosch and Gallopoulos 1989). Industrial ecology (IE) is defined as the design of industrial process and products and implementation of sustainable manufacturing strategies to seek to optimize the total materials cycles from virgin material to the component, to product to waste and disposal (Jelinski et al. 1992).

Frosch and Gallopoulos first presented the concept of the industrial ecosystem in 1989 in their article "Strategies for Manufacturing." This term is later termed as industrial ecology (Garner and Keoleian 1995). Industry ecology aimed to provide a better understanding of the impact of the industrial system on the environmental and involving interrelationship among product and process as well as among the firms. Industry ecology is a high level of system approach to reduce industrial ecological impacts on the environmental system (Garner and Keoleian 1995). Industrial ecology (IE) is a scientific study about the effects of the industrial system have on human and natural capital. IE represents an essential aspect that the earth is a closed system with limited resources and reduced waste capacity (Chertow and Ehrenfeld 2012). Understanding how business activities promote sustainable development requires the integration of IE thinking into management literature (Hoffman et al. 2014).

Sustainable Development Goal 12 (SDGs) of the 2030 agenda are about promoting resource and energy efficiency and sustainable infrastructure and providing a better quality of life for all (United Nations 2015). It contains the righteous slot to reinvigorate sustainable development, which is not only crucial for human well-being but also essential from a policy perspective (Filho et al. 2017). The philosophy behind the SDGs12 is to enhance the material efficiency with better life cycle planning and assessment of an industrial ecosystem that relies on an increased product service system among actors. It gives support for the use of green environmental criteria in product development plans, use of biomimicry, regenerative design, and cradle-to-cradle approach that directly and indirectly helps to achieve overall sustainable development plans. It improves future benefits of social, economic, and environmental development and provides opportunities for wellbeing of society. Scholars in industrial policy research have shown interest in social sustainability performance (Awan et al. 2018). Industrial ecology practices offer an initial understanding of the firms' sustainability strategies, which is increasingly considered important for sustainable development goals in improving overall sustainability. The management perspective opens a wealth of research opportunities that could draw upon implementation of a closed-loop system that can be functioned efficiently and effectively, or it can be combined to these ways for the design of the regenerative system, product service system, resource efficiency, and sustainable production and consumption. Much recent research focuses on the ability of the firm to promote collaboration and participation with different network participants' firms. The industrial ecology came to mean everything about the environmental needs, notably materials, impact on the natural and human capital. Therefore, there is a pressing need remnant to develop tools, modes, and frameworks on the 
industrial ecosystem to help the natural and human capital. There is a need to develop a conceptual framework to evaluate the opportunities for the manufacturers within the industrial ecosystem to the continuous development of industrial ecology.

\section{Historical View of Sustainable Development Goals}

The United Nation Sustainable Development Goals (UNSDGs) was introduced in September 2015 to describe a distinctive management approach of managing global challenges in multiple spheres of human and natural capital for sustainable development globally. The past decades have witnessed a quest for achieving Millennium Development Goals (MDGs) ranged from eradicating poverty and hunger to ensuring environmental sustainability. SDGs is an alternative goal that involves broader perspective and other global challenges to achieve the sustainable development, such as equality education, clean water and sanitation, affordable and clean energy, industry innovation and infrastructure, sustainable cities and communities, responsible consumption and production, climate action, and life on land. The difference lies in the MDGs that is taking the system boundary approach, whereas SDGs is taking a system approach. There has recently been a resuscitation of interest in the 17 SDGs and its 169 targets within the business sector. The UNSDGs 12 for sustainable development framework (Fig. 1) is made up of a set of 11 targets and 13 key indicators: implementing the 10-Year Framework of Programmes on Sustainable Consumption and Production Pattern (12.1); sustainable management and use of natural resources (12.2); halve per capita global food waste at the retail and consumer levels and reducing food losses along production and supply chains (12.3); responsible management of chemicals and waste management in all wastes throughout their life cycle (12.4); substantially reducing waste generation through prevention, reduction, recycling, and reuse (12.5); encouraging companies to adopt sustainable practices and sustainability reporting (12.6); promoting public procurement practices that are sustainable, in accordance with national policies and priorities (12.7); promoting universal understanding of sustainable lifestyles (12.5); supporting developing countries' scientific and technological capacity for sustainable consumption and production (12.A); developing and implementing tools to monitor sustainable development impacts for sustainable tourism (12.B); and removing market distortions that encourage wasteful consumption (12.C). SDGs12 is one of the most leading and widespread accepted frameworks in current global sustainability setting, providing bases to achieve a sustainable development agenda. 


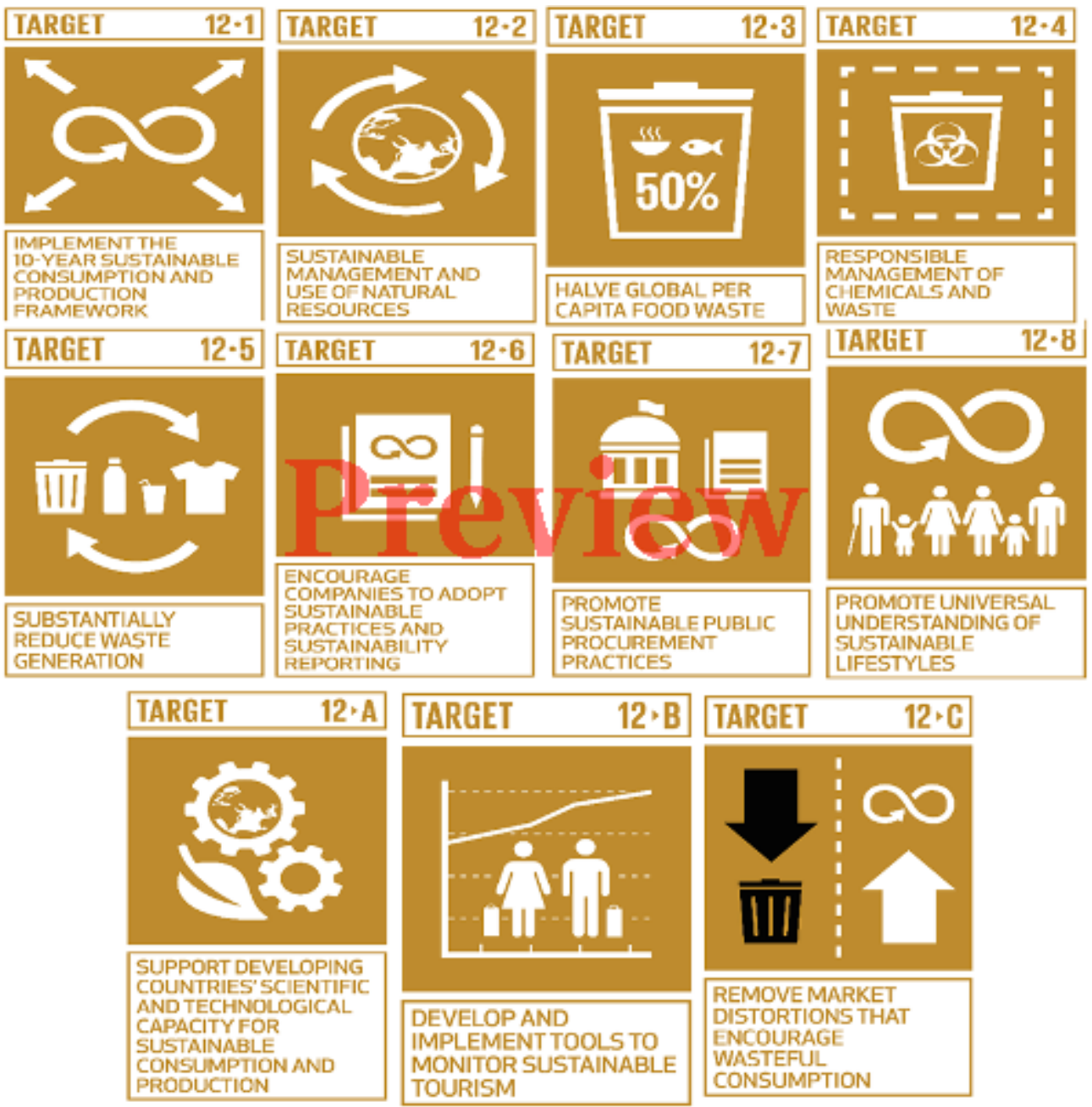

If you need to edit the image, please use the original: 457134_0_En_18-1_Fig1_Print.tif

Fig. 1

United Nations Sustainable Development Goals 12 targets. (Adapted by The Global Goals)

Research shows that there is increasing interest in discussion on sustainable development from the last 30 years. Beyond the increased interest in sustainability, it tends to form a global common agenda to overcome sustainability challenges and assist countries (Lange et al. 2019). However, despite renewed interest in these goals, progress in the area is still at precursory. The economic and financial benefits of current business activities have witnessed in the different industrial sector across the globe.

However, due to the recent ecological and climate issues, there has been a major shift in doing business. It calls for new business strategies and approaches for the transformation of existing global challenges into the engine of sustainable development by using industrial ecology tools to pursue sustainable development goals (Sullivan et al. 2018). Industrial ecology has a critical role to play in clinching the SDGs. United Nations Global Compact Environment Program 2000 mainly deals with commitment standards, whereas SA8000 (SAI 2014) is only concerned with the social dimension and hardly applicable to firms. Environment Management System (EMS) (European Commission 2007) is only an assessment tool for environmental measurement, whereas ISO 26000 (ISO 2010) is an environment assessment and social performance measurement framework and standard GRI (GRI 2007) articulated for firms to integrate three dimensions of sustainable performance in their operations. These both ISO2600 and GRI standards are not broadly applicable in sustainable development and not exhaustive (Chardine-Baumann and Botta-Genoulaz 2014). Environmental 
impact defined as a "Modification of the environment due to human intervention, which may be actual or supposed potential harmful impact on the natural or ecosystem and human health." Increasing concessional United Nations Conference on Trade and Development (UNCTAD) to support developing countries to undertaken sustainable production capacity was a central feature of United Nation Sustainable Development Goals envisaged in SDGs 12. Despite the prominence of the SDGs12 provided by industrial ecology for capacity building in developing countries has been limited discussion of the relationship between industrial ecology (IE) and sustainable production and consumption. Both IE and sustainable production and consumption engross with conceptions of achieving triple bottom-line goals to support UNSDGs, and it is essential to understand where the capacity of the sustainable output assists with the enactment of IE and where they support.

Industrial ecology, however, specifically could contribute in reducing waste, integrated chain management, life cycle costing and benefits, encouraging closed-loop production and consumption of material to networks, and relying on small- and large-scale networks of institutions and firms, which take special advantage of local and international cooperation. The development of close-loop product production and consumption in IE activities requires downstream and upstream participation throughout an integration and opportunity identification approach. As a consequence of potential sustainable development benefits of IE, industrial actors are increasingly interested in understanding their longer-term environmental challenges. Awan ( $\underline{2011}$ ) has shown the usefulness of environmentally friendly segment in energy markets. An industrial ecologist by no means uses effectively market segmentation strategies as support to sustainability initiatives. For example, particularly developing countries require law by their national governments on the creation of industrial ecology (IE) infrastructure. It is also argued that the successful implementation of IE requires governments to examine existing environmental policies and legislation to eliminate unnecessary barriers in developing an industrial policy for manufacturers, international marketing, operations, and circular economy practices. The United Nations Industrial Development Organization (UNIDO) and business and industry associations see the urgency to act upon the reformulation of this industrial policy area for sustainability. However, equally important as the first step, such as the launch of support funds for developing countries to support IE programs, is a bigger perspective to achieve a sustainable future.

\section{Industrial Ecosystem Versus Industrial Ecology}

The earliest work on industrial ecology (IE) was sparked (Frosch and Gallopoulos 1989). Further IE concepts used as a weapon for gaining competitive advantage and later debate opened whether incorporating environmental practices into the organizations can lead to reaping the economic benefits as well as a competitive advantage (Frosch and Gallopoulos 1989). Research into the positioning of business as part of industrial ecology has continued since (Frosch and Gallopoulos 1989) concept of the industrial ecosystem. Industrial ecology differs from the industrial ecosystem because industrial ecology deals with the interrelations among different factors in which one seeks to optimize material, resources, and capital (Graedel et al. 1995). For example, Kalundborg, Denmark, is the evolution of the industrial ecosystem, where Asanes, Denmark, has the largest power stations that discharge products of gypsum which go to Gyproc, a plasterboard factor used in wallboards. The industrial ecology tends to take a system perspective when to implement desired change that supports sustainability initiatives.

A traditional industrial ecological system is characterized at the micro-level (deals with problems of individual firms) and macro-level (deals with a total system). In a previous investigation of industrial 
ecology, a literature (Karn 2004) identified nine dominant themes, such as material and energy flow studies, dematerialization and decarbonization, technological change and the environment, life cycle planning, design and assessment design for the environment ("eco-design"), extended producer responsibility ("product stewardship"), eco-industrial parks ("industrial symbiosis"), productoriented environmental policy, and eco-efficiency. The industrial ecology is a system to ecological and human needs by imitating the natural flow of the system to converge from a traditional linear system of material flow to a closed-loop system. There are two popular approaches in the industrial ecology, (1) regional approach and (2) product chain approach (Boons and Howard-Grenville 2009). The first approach emphasizes on the eco-industrial parks, where similar and different firms are located with both economic and environmental benefits, whereas product chain involves all resources to develop products. Korhonen et al. suggest that IE is a kingpin on the manufacturing process as a model of sustainable industrial activity and views business as agent for sustainable products that provide routes to alter unsustainable industrial and business system (Korhonen 2004). With increasing environmental issues, the green consumption trend of using and conversing resources is prodigious, thereby exerting pressure on companies to position themselves as a socially responsible and environmentally friendly (Awan and Raza 2012).

Industrial ecology is of great importance to determining well-built and sustainable opportunities for growth of ecology and human. IE, however, specifically could contribute to reducing waste, encouraging closed-loop production, and consumption of material to networks relies on small- and large-scale systems of institutions and firms, which takes particular advantage of local and international cooperation. Industrial ecology contemporaneously constitutes a viable option for industries to transform energy and material efficiency into closed-loop flows and achieve sustainable development benefits. In addition to this approach, the term circular economy is vital for increasing the performance of industrial ecology.

\section{Industrial Ecology and Capacity for the Sustainable Production}

As industrial ecology becomes omnipresent than ever, sustainable development is becoming an essential theme in the ecological literature. The concept of industrial ecology and sustainable production offer a vantage point from which to understand the inter-firm environmental management system. Moreover, it assists in explaining what the system is and how it generates through the interaction of different actors in industrial ecological settings. Sustainable production linkages often between industrial networks of different sectors and thus requires communication and collaborations. Collaboration is defined as "the ability to collaborate among public and private organisations to bring about technological change" (Hart and Hart 1995). Internal and external actors cannot deliver sustainable production but can participate in the creation and offering of energyefficient and zero waste solutions. In the sustainable production of products and process, capacity is an important contributor to the development of sustainable solutions. In turn, capacity building is expected to increase the benefits of sustainable development (Shiel et al. 2016). Additionally, Avila et al. ( 2017) suggest the management competencies can also affect the deployment of sustainability initiatives. The green design of a firm's products is considered to be an important sustainable strategy (Awan 2011) to support the SDGs 12.

Conversely, in capacity development, internal firms' actors act as facilitators in the creation of sustainable process and products development. Emphasizing the active role of internal actors in shaping the network participants, collaboration is best to support networks commitments in terms of 
institutional networks. In an industrial ecological context, subjective actors' experience in identification of opportunity plays a central role in the formulation of collaboration. Thus, the capacity for sustainable production relates specifically to a realm of opportunity identification and assessment with internal actors and consciousness cooperation with the external actor. Thus, the development of capacities also encompasses elements of the adaptive style of management. Institution's support to the firms is concerned with the competencies and firm relations to its external competitive environment. The quest for the collaboration of internal actors should understand in terms of its possession of capacities for opportunity identification and assessment. Capacity development, however, is intrinsically a matter of specific and details of opportunity identification and assessment.

\section{Circular Economy and Sustainable Consumption and Production Issue}

Due to climate change challenges and awareness about greenhouse gas emission, different interest groups engaged with manufacturing firms to build to focus on an industrial system that designed products for the cycle of disassembly and reuse. Stakeholder's engagement is a key vehicle for the implementation of new ideas for the development of circular economy practices. Taken together, buyer-supplier relationship and sustainability literature suggest that firms must apply different approaches to exchange interaction to the development of innovative solutions for sustainable performance. Even though this point of view emphasizes the multi-actor network management of sustainability, it is not thus far explained how precisely these stakeholders extend across interlinked stages of a circular economy.

Industry ecology is a high level of system approach to reduce harmful industrial systems' environmental impacts on the ecological system (Garner and Keoleian 1995). Business practices related to "sustainability are an approach which firms adopt by altering or modifying their current established practices and rules" (Engardio et al. 2007). As an example, Kumpi, Finland, is helping to make cluster decisions that disregard the national infrastructure strategies. Furthermore, the infrastructure planning processes created by the local and national government somewhat are not aligned with each other, developing a planning maze for recycling initiatives. This problem is not limited to this region; the firm has closed operations less than a year, undermining future recycling investment, laying off 40 staff. Finland is a pioneer in the circular economy initiatives, and business enterprises in Finland have functional expertise to generate a circular economy benefit of other stakeholders for both present and future. However, the transition towards a circular economy requires to fully understand what infrastructure process is essential that supports recycling and remanufacturing. Even though numbers have already been published on waste generations, for all the intents and purpose, circular economy (CE) signifies providing the products' demands to society through recycling, remanufacturing, and reusing where possible. In addition to this approach, the term circular economy is vital for increasing the performance of industrial ecology.

The ongoing industrialization has led to enormous environmental challenges and issues from manufacturing industries. Kirchherr et al. ( 2017) discussed opportunities for the firms for sustainable development. Lieder and Rashid ( 2016 ) found in their research that CE leads to decrease environmental degradation, save natural resources, and improve the reproductive capacity. The wellknown visualization strategies (reuse, repair, remanufacture, recycle, and refurbish) of the circular economy are provided by the EllenMacArthur Foundation (EMF) (Bocken et al. 2017). There have been some discussions in the literature about the role of reuse and remanufacture in establishing and 
supporting the CE principles, developing prolong use of and reuse of goods over time, aimed at narrowing loops associated with the use and reuse of products and process (Bocken et al. 2017). In $\mathrm{CE}$, "the concept of waste is eliminated by carefully designing products and industrial processes in such a way that materials are perpetual." The most important reason for not recycling many products is the lack of customized practices and lack of focus on collection and consumption patterns. The $3 \mathrm{R}$ concept of circular economy, reduce, reuse, and recycle, has become central to the global economy (Murray et al. 2017). The design of product involves in manufacturing by-products, producing byproducts, and product extension and end-of-life and recovery process in addition to the other aspects of the supply chain (Linton et al. 2007). According to Golroudbary and Zahraee ( 2015), companies should encourage to develop the capacity that can incorporate both reverse and forward flow of goods simultaneously. The Ellen MacArthur Foundations depict the concerns of the circular economy for an industrial system that is restorative by design are to take full advantage of reusability of the products through reducing and recycling process (EllenMacArthur Foundation 2013). In practice, broad variations of implementation of CE practices with some firms pursuing more of this through governmental collaborations and nongovernmental organizations. The concept of circular economy practices evolved differently in different parts of the world (Winans et al. 2017) and is still evolving in green supply chain management, industrial symbiosis, and biomimicry field. Circular economy (CE) initiatives include the idea of reusing and recycling (Kirchherr et al. 2017; Stewart and Niero 2018). Recycling is another key dimension of circular economy in circularity ecosystem, which, in practice, is a shift from the end-of-life products to continuous use of materials within operations (Haas et al. 2015). The inner loops of reusing and remanufacturing are preferred (Mihelcic et al. 2003). Materials should "first recovered for reuse, refurbishment and repair than for remanufacturing and only later for raw material utilisation" (Korhonen et al. 2018). Industrial ecology and circular economy go hand in hand. IE represents important tools that may support the process in transition to the circular economy (CE), where CE does not just assume looking forward to transforming the linear to closed-loop materials and energy flows but also provides resources to be used for a better ecology and human future. The role of IE in the ecological building process is increasingly emphasized. Many industrial actors have incorporated IE and CE as part of their policy agenda, including in their reporting initiatives. Industrial ecology is a vital element of sustainable development.

\section{Industrial Ecology and Capacity for Sustainable Production: The Intersection}

The multi-actor cooperation can influence the identification of opportunities through identifying the use of energy-efficient resource to transform a by-product into a valuable, reusable resource. Although opportunity identification through close interaction between actors is sometimes successful, stumbling to envisage often halts these opportunities from realization, and barely the capacity building approaches are considered as a core of the more comprehensive strategy. Capacity assessment appraises the outcomes equate with a new sustainable production process. Typically, this is done with an evaluation of a product's impact on climate change from the raw material extracted. Despite the importance of sustainable production and industrial ecology (IE), to date, there has been limited academic attention on the relationship between industrial ecology and capacity development. Building on IE and capacity literature, this section outlines a theoretical framework for understanding how opportunity identification and assessment might act as a facilitator to sustainable production. The possible $5 \mathrm{Cs}$ of opportunity identification approaches have been synthesized by 
Anthony Scott ( 2012): (1) circumstance, (2) context, (3) constraints, (4) compensating behaviors, and (5) criteria. Within any firm, the capacity of opportunity identification is aimed to solve problems of sustainable development through system boundaries, social embeddedness, and institutional supports. The idea of $5 \mathrm{Cs}$ of opportunity identification is a convenient way to identify whether a firm has adequate resources and acts very divergently in the process of sustainable development to visualize opportunities for sustainable production and consumption.

According to Awan et al. ( 2017), the development of cleaner production technologies and internal capability is a key strategy to meet the demands of external stakeholders. The climate responsiveness of customers and the increase green business image in the market steadily have poked industries to think about sustainable consumption and production using implementing industrial ecology initiatives. Context, in opportunity identification, is a key player and a driver for sustainable development. By applying this perspective, a firm may find a way to be with the customer as to find ways to use their industrial by-product waste to be used either in a process or as a product. Nevertheless, managers could discover the process of decarbonization, life cycle planning of products, eco-design initiatives, and product-oriented eco-efficiency and stewardship issues. There is an increasing body of knowledge on the importance of networks advancing the environmental performance and can contribute to the various sustainability indicators. Networks of firms enable them to acquire, develop, and transform the knowledge and information that advances to the more responsible management of waste, encouraging sustainable consumption and production and encouraging closed-loop consumption of materials. Constraints analysis may help firms to find better ideas for redesigning the process and products, and it often results in the discovery of new ideas, for example (Awan et al. 2019).

Compensating behavior (CB) has been regarded as an important determinant whether modification of existing process has a value for the firm profitability. CB is a treadmill, and it is vital to keep running to stay on the top of competitive advantage. It is suggested that CB affects worker's ability to improve productivity and its ability to anticipate opportunities and problems that are in the interest of the management. Criteria are not just a push button to select without behavioral repertoire, but it implies they think things through and debated within system boundaries. Boundary theory emphasizes how organizational members should maintain a collaborative relationship with their suppliers. Boundary theory grew from a stream of research about how to bridge the boundary between suppliers and their customers (Aldrich and Herker 1977). Lau et al. ( 2010) point out the importance of the acquisition of knowledge resources as input from customers, such as "idea, information about their needs for new product and process development" influence on innovation and performance. There have been some studies that used boundary theory on aspects of bridging the boundary between suppliers and customers, sharing of knowledge for innovation (Maria Stock et al. 2017). Gemünden et al. ( 2007 ) have applied boundary for investigating radical innovations in times of open innovation. The finding suggests that individual role in particular creates interorganizational links with outside the organizational members. Boundary theory identified various organizational factors and "thus relies upon the expertise and discretion of its boundary role personnel" (Aldrich and Herker 1977).

The criteria are a set of standard procedures for IE through which a decision made, what is optimally suitable for a particular situation. Thus, the formal procedure is not merely used but instead to apply for restructuring resources. Based on the components of industrial ecology discussed in the previous section, it offers a means for understanding the future trends in sustainable production and consumptions. Internal actors for capacity development intended to provide institutional arrangements to help change the use of the existing consumption patterns, to use of one particular set of opportunity identification. While sustainable production has probable to make consequential contributions to SDGs12, there left some substantial uncertainty about the appropriate institutional 
role and policy program aimed at the development commitment to industrial ecology. In this regard, opportunity identification approach could be something of a two-edged sword. If it is used and applied passably and in line with energy and resource efficiency, it could be an effective tool to support SDGs12 and a companion to industrial ecology, and if it is not exercised and applied by energy and resource limits, it could have an inauspicious effect and be sidelined by industrial ecology. Energy and resource management are considered to be important growth strategies for firms. Recently, Awan et al. ( 2014) suggest that energy management approaches are also important in describing differences in sustainable development goals, although they suggest that energy management is the fourth pillar of sustainable development.

\section{Conclusion}

The growing research interest in industrial ecological (IE) provides tools for leveraging the opportunity identification to facilitate SDGs12. This study demonstrates that industrial ecology emphasizes the need for an opportunity identification perspective in decision making, contemplating the use of resources in ways it represents system boundaries. The aim of the boundaries is to forepart critical sources for energy and waste inefficiencies that hinder to achieve SDGs12. Opportunity identification process enables firms to continue with current practices with only incremental change in inter-firm relationships for responsible production and consumption patterns, material and energy flow reduction, product utilization of resources (biomass, fossil fuels, metal ores, and non-metal ores), minimization of food waste, responsible business management for waste reduction, generation through recycle and reuse throughout their life cycle, sustainability reporting, green and clean public procurement practices, and civic and responsible management education. The conclusion is that established marketing and management practices are not designed to assist managers in decision making for specific implementation industrial ecology strategy for achieving a decent number of SDG12 targets.

The responsible future for the upcoming generation, UNSDGs 2030 offers an attempt to interpret the future in a holistic, systematic way, to inspire practitioners and academicians to apply system thinking approach about the manufacturing industries to redesign marketing, operations, digital and environmental practices, and policies that are expected to be required to support climate challenges. Hence, industrial ecology must be recognized as offering sustainable solution; rather, they serve as riding on two horses, which should be helpful in strategic planning and economic benefits. Since the manufacturing industry is small meteoric changing and the environmental and economic balance is shifting, the cost of saving the planet from brinkmanship will be exceptionally high and might jeopardize its forbearance future of responsible firm which relies on implementation and promotion of industrial ecological practices driven by leading firms. Reanalyzing priorities and searching new industrial policies areas in operations and marketing departments is of an urgent need to face the future generation better.

Industrial ecology adaptations aim to maximize the utilization of natural resources and minimize risk from climate change. The future model of manufacturing firms goes beyond institutional compliance and beyond zero pollution. I suggest that industrial ecology transformation entails not only redesigning of the company industrial marketing practices, business innovation models, and intrapreneurship principles but also of the resource sharing relationship between firms, governments, and societies at the local, regional, national, and global level. The incentive and promotion programs represent a tool for developing an action plan on IE. The marketing promotion programs may act as a bridge between the industrial organization and decision makers, supporting the best ecological 
actions guiding future collaborative management choices. Such collaborative management arrangements on a collection of reuse and end-of-life products between the industrial actors can also generate a positive competition between other clusters of firms. A prevalent theme in strategic innovation management and marketing is that firm should increasingly need to rely on life cycle management capability, material flow analysis capability, environmental design capability, waste management capabilities, the orientation of extended producer responsibility, and low-carbon management capability. Export manufacturing industries need to find the right balance between standardization of industrial ecology practices and adaptations to the foreign markets which will be a key to international market growth, export growth, and expansion to new markets. Current debates on international business and marketing strategy indicate that a lack of key industrial ecological capabilities is a hurdle to expand into new international markets. There has been little research focusing on industrial ecology capabilities' impact on internationalization, export performance and entry into new markets. The evidence suggests that SDG may be an appropriate tool for the establishment of global industrial ecology initiatives, notably in all industries. Managers can take advantage strongly from opportunity identification approach. IE provides possible research avenues in many fields, such as management, marketing, industrial engineering, geographical information system, food chemical, and electronic industries. Overall, industrial ecology tools and concepts can be used to improve the efficiency of raw materials.

\section{Cross-References}

. Business Environment

. Circular Economy

- Eco-Industrial Parks

\section{References}

Aldrich H, Herker D (1977) Boundary spanning roles and organization structure. Acad Manag Rev 2:217-230. https://doi.org/10.5465/AMR.1977.4409044

CrossRef

Anthony S (2012) The five Cs of opportunity identification. Harv Bus Rev. https://hbr.org/2012/10/ the-five-cs-of-opportunity-identifi. Accessed 09 June 2019

Ávila LV, Leal W, Brandli L et al (2017) Barriers to innovation and sustainability at universities around the world. J Clean Prod 164:1268-1278. https://doi.org/10.1016/j.jclepro.2017.07.025

CrossRef

Awan U (2011) Green marketing: marketing strategies for the Swedish energy companies. Int J Ind Mark 1:1-19. https://doi.org/10.5296/ijim.v1i2.1008

CrossRef 
Awan U, Raza MA (2012) Green consumer behavior: empirical study of swedish consumer behavior. Recent Res Econ. pp 89-104

Awan U, Imran N, Munir G (2014) Sustainable development through energy management: issues and priorities in energy savings. Res J Appl Sci Eng Technol 7:424-429

CrossRef

Awan U, Kraslawski A, Huiskonen J (2017) Understanding the relationship between stakeholder pressure and sustainability performance in manufacturing firms in Pakistan. Procedia Manuf 11:768-777

CrossRef

Awan U, Kraslawski A, Huiskonen J (2018) Buyer-supplier relationship on social sustainability: moderation analysis of cultural intelligence. Cogent Bus Manag 5:1429346. https://doi.org/10.1080/ 23311975.2018.1429346

CrossRef

Awan U, Sroufe R, Kraslawski A (2019) Creativity enables sustainable development: supplier engagement as a boundary condition for the positive effect on green innovation. J Clean Prod 226:172-185. https://doi.org/10.1016/j.jclepro.2019.03.308

CrossRef

Bocken NMP, Olivetti EA, Cullen JM et al (2017) Taking the circularity to the next level: a special issue on the circular economy. J Ind Ecol 21:476-482. https://doi.org/10.1111/jiec.12606

CrossRef

Boons F, Howard-Grenville JA (2009) The social embeddedness of industrial ecology. Edward Elgar Publishing, Cheltenham

CrossRef

Chardine-Baumann E, Botta-Genoulaz V (2014) A framework for sustainable performance assessment of supply chain management practices. Comput Ind Eng 76:138-147. https://doi.org/10. 1016/j.cie.2014.07.029

CrossRef

Chertow M, Ehrenfeld J (2012) Organizing self-organizing systems: toward a theory of industrial symbiosis. J Ind Ecol 16:13-27. https://doi.org/10.1111/j.1530-9290.2011.00450.x 


\section{CrossRef}

EllenMacArthur Foundation (2013) Towards the circular economy:economic and business rationale for an accelerated transition. Cowes, Ellen MacArthur Foundation

Engardio P, Capell K, Carey J, Hall K (2007) Beyond the green corporation: imagine a world in which eco-friendly and socially responsible practices actually help a company's bottom line. It's closer than you think. Bus Week 4019:50

European Commission (2007) EACH in brief. Environment directorate general. European Commission, Brussels

Filho WL, Ulisses A, Alves F et al (2017) Reinvigorating the sustainable development research agenda: the role of the sustainable development goals (SDG). Int J Sustain Dev World Ecol 00:1-12. https://doi.org/10.1080/13504509.2017.1342103

CrossRef

Frosch RA, Gallopoulos NE (1989) Strategies for manufacturing. Sci Am 261:144-152 CrossRef

Garner A, Keoleian G (1995) Industrial ecology: an introduction. Pollution prevention and industrial ecology. National Pollution Prevention Center for Higher Education. pp 1-32. https://pdfs. semanticscholar.org/d352/711b1a4565065afb09bbb0113e553ad757d2.pdf. Accessed 29 May 2019

Gemünden HG, Salomo S, Hölzle K (2007) Role models for radical innovations in times of open innovation. Creat Innov Manag 16:408-421

CrossRef

Global Reporting Initiative (2007) The GRI's Sustainability Report July 2004 - June 2007

Golroudbary SR, Zahraee SM (2015) System dynamics model for optimizing the recycling and collection of waste material in a closed-loop supply chain. Simul Model Pract Theory 53:88-102. https://doi.org/10.1016/j.simpat.2015.02.001

CrossRef 
Graedel TE, Allenby BR, Comrie PR (1995) Matrix approaches to abridged life cycle assessment. Environ Sci Technol 29:134A-139A

CrossRef

Haas W, Krausmann F, Wiedenhofer D, Heinz M (2015) How circular is the global economy?: an assessment of material flows, waste production, and recycling in the European union and the world in 2005. J Ind Ecol 19:765-777. https://doi.org/10.1111/jiec.12244

CrossRef

Hart SL, Hart SL (1995) A natural-resource-based view of the firm. Acad Manag Rev 20:986-1014. https://doi.org/10.5465/AMR.1995.9512280033

CrossRef

Hoffman AJ, Corbett CJ, Joglekar N, Wells P (2014) Industrial ecology as a source of competitive advantage. J Ind Ecol (5):597-602

CrossRef

ISO (2010) 26000 Guidance on social responsibility. Ginebra: ISO

Jelinski LW, Graedel TE, Laudise RA et al (1992) Industrial ecology: concepts and approaches. Proc Natl Acad Sci 89:793-797

CrossRef

Karn BP (2004) Small stuff, big opportunity for industrial ecologists. International Society for Industrial Ecology. Newsletter 4(4): 1, 3-4

Kirchherr J, Bour R, Kostense-Smit E et al (2017) Barriers to the circular economy: evidence from the European Union (EU). Ecol Econ 150:264-272. https://doi.org/10.1016/j.ecolecon.2018.04.028 CrossRef

Korhonen J (2004) Industrial ecology in the strategic sustainable development model: strategic applications of industrial ecology. J Clean Prod 12(8-10):809-823. https://doi.org/10.1016/j.jclepro. 2004.02.026

CrossRef

Korhonen J, Honkasalo A, Seppälä J (2018) Circular economy: the concept and its limitations. Ecol Econ 143:37-46. https://doi.org/10.1016/j.ecolecon.2017.06.041

CrossRef 
Lange A, Leal W, Londero L, Sapper J (2019) Assessing research trends related to sustainable development goals: local and global issues. J Clean Prod 208:841-849. https://doi.org/10.1016/j. jclepro.2018.09.242

CrossRef

Lau AKW, Tang E, Yam RCM (2010) Effects of supplier and customer integration on product innovation and performance: empirical evidence in Hong Kong manufacturers. J Prod Innov Manag 27:761-777

CrossRef

Lieder M, Rashid A (2016) Towards circular economy implementation: a comprehensive review in context of manufacturing industry. J Clean Prod 115:36-51. https://doi.org/10.1016/j.jclepro.2015. 12.042

CrossRef

Linton JD, Klassen R, Jayaraman V (2007) Sustainable supply chains: an introduction. J Oper Manag 25:1075-1082

CrossRef

Maria Stock R, Zacharias NA, Schnellbaecher A (2017) How do strategy and leadership styles jointly affect co-development and its innovation outcomes? J Prod Innov Manag 34:201-222. https:// doi.org/10.1111/jpim.12332

CrossRef

Mihelcic JR, Crittenden JC, Small MJ et al (2003) Sustainability science and engineering: the emergence of a new metadiscipline. Environ Sci Technol 37:5314-5324. https://doi.org/10.1021/ es034605h

CrossRef

Murray A, Skene K, Haynes K (2017) The circular economy: an interdisciplinary exploration of the concept and application in a global context. J Bus Ethics 140:369-380. https://doi.org/10.1007/ s10551-015-2693-2

CrossRef

Shiel C, Leal W, Pac A, Brandli L (2016) Evaluating the engagement of universities in capacity building for sustainable development in local communities. Eval Prog Plann 54:123-134. https://doi. org/10.1016/j.evalprogplan.2015.07.006

CrossRef 
Social Accountability International (SAI) (2014) http://www.sa-intl.org/. Accessed 10 Jun 2019

Stern FR (1973) The varieties of history: from voltaire to the present. Vintage 2nd ed. edition. New York: Random House

Stewart R, Niero M (2018) Circular economy in corporate sustainability strategies: a review of corporate sustainability reports in the fast-moving consumer goods sector. Bus Strateg Environ:118. https://doi.org/10.1002/bse.2048

CrossRef

Sullivan K, Thomas S, Rosano M (2018) Using industrial ecology and strategic management concepts to pursue the sustainable development goals. J Clean Prod 174:237-246. https://doi.org/10. 1016/j.jclepro.2017.10.201

CrossRef

United Nations (2015) Transforming our world: the 2030 agenda for sustainable development. Resolution Adopted by General Assembly. https://sustainabledevelopment.un.org/post2015/ transformingourworld. Accessed 02 June 2019

Winans K, Kendall A, Deng H (2017) The history and current applications of the circular economy concept. Renew Sust Energ Rev 68:825-833. https://doi.org/10.1016/j.rser.2016.09.123

CrossRef 